\title{
ADOLESCENT KNOWLEDGE LEVEL ABOUT CERVIC CANCER PREVENTION
}

\author{
Henni Safrida Sitompul ${ }^{1}$ \\ ${ }^{1}$ Akademi Keperawatan Colombia Asia \\ *Corresponding Author: henni.safrida@yahoo.com
}

\begin{abstract}
Cervical cancer is the most common cancer among women. Cervical cancer attacks the female reproductive organs and uterus. Every year thousands of women die from cervical cancer. Poor living habits can also cause outbreaks of cervical cancer, such as smoking, lack of nutrition, longterm use of oral contraceptives, sexual activity that is often among adolescents. The level of knowledge of young women about cervical cancer prevention in the Mayjend Sutoyo College Foundation Senior High School Medan. World Health Organization (WHO) states, currently cervical cancer is ranked among the various types of cancer that causes death in women in the world. Cervical cancer can be prevented by doing primary prevention and secondary prevention. This type of research is a descriptive study conducted. The population in this study were female students at the MayjendSutoyo College Foundation in Medan. A sample of 39 people were taken in total sampling. Data obtained using a questionnaire. The conclusion of the study is the level of knowledge of young women in the Mayjend Sutoyo Medan Foundation High School in the prevention of cervical cancer is still in the sufficient category.
\end{abstract}

Keywords: Cervical Cancer Prevention, Knowledge, sufficient

\section{PRELIMINARY}

Cervical cancer or cervical cancer is the most common cancer in women. Cervical cancer attacks the reproductive organs of women, precisely in the cervix at the bottom between the female reproductive organs and the uterus. Every year thousands of women die from cervical cancer (Redmond, 2010). Cervical cancer is caused by the Human Papilloma Virus (HPV) which is transmitted through sexual intercourse or intimate relationships (premarital sex) with men who often change partners at an early age of $<16$ years, this can increase the risk of cervical cancer. Poor living habits can also cause cervical cancer, such as smoking habits, lack of nutritional intake, use of oral contraceptives for a very long time, frequent sexual activity among adolescents, and parity (the number of births more or more often) (Yanty, 2013).

According to a survey involving 5,423 Asian women and conducted in 9 countries, including Indonesia, it is proven that only $2 \%$ of women know that HPV infection is the cause of cervical cancer. The results of Dhani Arief Prandana's research at the RSUP. H. Adam Malik Medan in 2011 with cervical cancer (ca cervical) as many as 367 people. The most age group is 40-55 years old (58.3\%). Most cancer patients have junior-high school education status (57.2\%). The highest parity is $56.1 \%$ (Masriadi, 2016). Adolescence is a period of transition in which physical and psychological changes from childhood to adulthood. Psychological changes that occur in adolescence include intellectual, emotional and social life. Physical changes include sexual organs, namely the reproductive organs have reached maturity and are starting to function properly (Sarwono, 2010). 
Adolescence is defined as a period of developmental transition from childhood to adulthood, which includes aspects of biological, cognitive, and social changes that take place between the ages of 10-19 years (Santrock, 2010).

\subsection{Youth Health Problems}

The recommended examinations for women are Papanicolaou (Pap smear), Gonorrhea and Chlamydia cultures from cervical preparations, and syphilis examination. Meanwhile, for men, culture of gonorrhea and Chlamydia from the urethra and examination of syphilis are recommended (Perry \& Potter, 2009). Cervical cancer or cervical cancer is cancer in the female reproductive system, which is the entrance to the uterus which is located between the uterus (uterus) and the vagina (vagina). Cervical cancer occurs characterized by the growth of cells in the cervix that are not uncommon (abnormal) (Kartikawati, 2013).

Cervical cancer attacks the mouth or cervix. This part is the lower part of the uterus that protrudes into the cavity in the vagina (Masriadi, 2016). Changes in the cervix are usually asymptomatic and these changes go undetected unless the woman undergoes a pelvic exam and pap smear. Symptoms usually only appear when abnormal cervical cells turn into malignancy and infiltrate the surrounding tissue. Primary prevention is an effort to reduce or eliminate individual contact with carcinogens to prevent the process of carcinogenesis. Primary prevention can be done through education, namely by consulting doctors about the importance of cervical cancer prevention and promotion or counseling of healthy lifestyles which include living healthy lifestyle behaviors.

Secondary prevention aims to find early cases of cervical cancer, so that the chances of cure can be increased. Secondary prevention includes screening and early detection programs, such as: Pap smears, coloscopy, and IVA tests. Secondary prevention is carried out based on the patient's risk, namely patients with moderate risk, a one-year examination and on the advice of a doctor is highly recommended.

\section{RESEARCH METHOD}

\subsection{Location}

The location of this research was carried out at the Mayjend Sutoyo College Foundation Senior High School, Medan, Indonesia in 2019.

\subsection{Research time}

The research was conducted from the submission of the title until the results of the study began in April to September 2019. The time for data collection or collection was from August 1 to August 31, 2019 (for 1 month).

\section{RESEARCH RESULT}

Table 1. Frequency Distribution of Knowledge Levels of Young Women About Cervical Cancer Prevention Based on Experience at Mayjend Sutoyo Foundation Senior High SchoolMedan 2019 


\begin{tabular}{lcc}
\hline Experience & Frequency(f) & percentange (\%) \\
\hline $\begin{array}{l}\text { Family members have } \\
\text { Having cervical cancer }\end{array}$ & 1 & $2.6 \%$ \\
& & \\
Family members who & $\mathbf{3 8}$ & $97.4 \%$ \\
$\begin{array}{l}\text { Never experienced } \\
\text { Cervical cancer }\end{array}$ & $\mathbf{3 9}$ & $\mathbf{1 0 0 \%}$ \\
\hline
\end{tabular}

From the table above, it can be seen that the level of knowledge of young women about cervical cancer prevention based on experience shows that the majority of respondents whose family members have never had cervical cancer are 38 people (97.4\%), and the minority of respondents whose family members have experienced cervical cancer is 1 people $(2.6 \%)$.

Table 2. Frequency Distribution of Knowledge Levels of Young Women About Cervical Cancer Prevention Based on Information Sources at Mayjend Sutoyo Foundation Senior High School Medan 2019

\begin{tabular}{|c|c|c|}
\hline Resources & Frequency(f) & Percentage $(\%)$ \\
\hline Print media & 10 & $25,6 \%$ \\
\hline Electronic Media & 20 & $51,3 \%$ \\
\hline Not Average & 9 & $23,1 \%$ \\
\hline Total & 39 & $100 \%$ \\
\hline
\end{tabular}

From the table above, it can be seen that the level of knowledge of young women about cervical cancer prevention based on information sources shows that the majority of respondents using electronic media are 20 people $(51.3 \%)$, and the minority of respondents using non-media are 9 people $(23.1 \%)$.

Table 3. Frequency Distribution of Knowledge Level of Young Women About Cervical Cancer Prevention in Mayjend Sutoyo Foundation Senior High School Medan

\begin{tabular}{|c|c|c|c|}
\hline $\begin{array}{l}\text { Knowledge level } \\
\text { Good }\end{array}$ & $\begin{array}{l}\text { Frequency(f) } \\
5\end{array}$ & $\begin{array}{c}\text { Percentage }(\%) \\
12,8 \%\end{array}$ & \\
\hline Enough & & 21 & $53,9 \%$ \\
\hline Less & 13 & $33,3 \%$ & \\
\hline Total & & & \\
\hline
\end{tabular}

From the table above, it can be seen that the level of knowledge of the majority of respondents is moderately knowledgeable as many as 21 people (53.9\%), and the minority of respondents who have good knowledge are 5 people (12.8)

\section{DISCUSSION}

Experience as a source of knowledge is a way to obtain the truth and by repeating the knowledge gained in solving problems faced in the past. Experience can also be obtained from one's own 
experience and the experience of others (Notoatmodjo, 2010). Experience is everything that is gained by young women from past events. The experience can be like a family member who has had cervical cancer. Information is data that has been processed into a form that has meaning for the recipient and has real value and feels current or future satisfaction, information that comes from the sender of the message addressed to the recipient of the message so as to produce a change or increase in knowledge (Notoatmodjo, 2010).

Source of information is all information obtained by young women either through print media, electronic media or non-media that can increase knowledge in nature. Of the three sources of information, both can increase one's knowledge. The more a person gets information, the more knowledge that person has. Based on the research results, the researcher's assumptions conclude that the level of knowledge of young women is still in the sufficient category. And knowledge about cervical cancer prevention is not yet fully known by young women because experience and sources of information can also have a short-term effect resulting in changes or increased knowledge.

\section{CONCLUSION}

Knowledge Level of Young Women About Cervical Cancer Prevention at the College Foundation Senior High School, Mayjend Sutoyo to 39 respondents. It is known that the majority of respondents have sufficient knowledge. It can be concluded that the level of knowledge of young women about cervical cancer prevention in SMA Foundation College Sutoyo is sufficient because young women do not receive health education about cervical cancer prevention.

\section{REFERENCE}

Arikunto, S. 2010. Research Procedure A Practical Approach. Jakarta.Rineka Cipta

Indonesian Ministry of Health. 2016. Indonesian Health Profile. Available at .http://www.Depkes.go.id. Retrieved on 07 March 2019.

Delima, Nur, et al. 2016. "Cervical Cancer Prevention Behavior in College Students

Faculty of Public Health, University of Halu Oleo in 2016. Kendari. Accessed on 07 March 2019.

Diananda R. 2009. A Complete Guide to Cancer. Yogyakarta: Mirza Media

Emilia. 2010. Prevention of Cervical Cancer. http://KTI-Jurnal.Pdf. Retrieved on 07 March 2019.

Kartikawati, Erni. 2013. Watch out!!!The Dangers of Cervical Cancer. Bandung: New Book.

Notoatmodjo, S. 2010. Behavioral Health Sciences. Jakarta: PT Rineka Cipta.

.2018. Health Research Methods. Jakarta: PT Rineka Cipta.

Masriadi, H. 2016. Epidemiology of Non-Communicable Diseases. Jakarta: CV Trans Info Media

Perry, Potter. 2009. Fundamentals of Nursing. Edition 7. Jakarta: Salemba Medika

Rasjidi, Imam. 2009. Early Detection \& Prevention of Cancer in Women. Jakarta: Sagung Seto.

Redmon. 2010. Definition of Cervical Cancer. Jakarta: Libraries. Rihama

Santrock JW, 2010. Educational Psychology Second Edition. Jakarta: Kencana Prenada Media Group.

Sarwono. 2010. National Reference Book for Gynecological Oncology. Jakarta: PT Bina Pustaka Sarwono Prawirohardjo.

Tamara, Patricia. 2006. "Overview of Adolescent Knowledge About Cervical Cancer Prevention in Level I Students of Nursing Department, Health Polytechnic, Kendari Ministry of Health in 2016". Retrieved on 07 March 2019. 
World Health Organization. 2010. WHO/ICO (Institut Catalad'Oncologia) Information Center on HPV and Cervical Cancer (HPV Information Centre). Indonesia: Human Papilloma Virus and Related Cancer. Summary Report Update.http://apps.who.int/hpvcentre. Retrieved on 07 March 2019.

Wiknjosastro, Hanifa, et al. 2009. Content Science. Jakarta: PT Bina Pustaka Sarwono Prawirohardjo.

Yanty, Vidi, Novita. 2013. "The Correlation of Mother's Knowledge Level About Cervical Cancer With Mother's Behavior In Performing Pap Smear Tests in North Tugu Village in 2013". Jakarta. Scientific Journal of FKIK UIN Syarif Hidayatullah Jakarta. Retrieved on 07 March 2019. 
Volume 1 No 2 (2021)

Adolescent Knowledge Level About Cervic Cancer Prevention DOI: 10.54443/ijerlas.v1i2.86 